Citation: Maracahipes, L., B. S. Marimon, E. Lenza, B. H. Marimon, E. A. de Oliveira, H. A. Mews, L. Gomes, and T. R. Feldpausch (2014), Post-fire dynamics of woody vegetation in seasonally flooded forests (impucas) in the Cerrado-Amazonian Forest transition zone, Flora, 209(5-6), 260-270, doi:10.1016/j.flora.2014.02.008.

\title{
POST-FIRE DYNAMICS OF WOODY VEGETATION IN SEASONALLY FLOODED FORESTS (IMPUCAS) In THE CERRADO-AMAZONIAN FOREST TRANSITION ZONE Leandro Maracahipes ${ }^{\mathrm{a}, \mathrm{b}}$, Beatriz Schwantes Marimon ${ }^{\mathrm{c}, *}$, Eddie Lenza ${ }^{\mathrm{c}}$, Ben Hur Marimon- Junior $^{\mathrm{c}}$, Edmar Almeida de Oliveira ${ }^{\mathrm{a}, \mathrm{b}}$, Henrique Augusto Mews ${ }^{\mathrm{d}}$, Letícia Gomes ${ }^{\mathrm{a}}$ and Ted R. Feldpausch ${ }^{\mathrm{e}}$
}

${ }^{a}$ Universidade do Estado de Mato Grosso (UNEMAT), Programa de Pós-graduação em Ecologia e Conservação, Nova Xavantina, MT, 78690-000, Brazil

${ }^{b}$ Universidade Federal de Goiás, Programa de Pós-Graduação em Ecologia e Evolução, Goiânia, GO, 74001-970, Brazil

${ }^{c}$ UNEMAT, Departmento de Ciências Biológicas, Caixa Postal 08, Nova Xavantina, MT, 78690000, Brazil

${ }^{d}$ Universidade de Brasilia, Programa de Pós-graduação em Ciências Florestais, Brasília, DF, 70919-970, Brazil

${ }^{e}$ Geography, College of Life and Environmental Sciences, University of Exeter, Exeter, United Kingdom

*Corresponding author: E-mail address: biamarimon@hotmail.com (B.S. Marimon).

\section{ABSTRACT}

Fire disturbance alters the structural complexity of forests, above-ground biomass stocks and patterns of growth, recruitment and mortality that determine community temporal dynamics. These changes may alter forest species composition, richness, and diversity. We compared changes in recruitment, mortality, and turnover time over three years between burned and 
unburned sites of two impucas (seasonally flooded natural forest patches in a predominantly savanna landscape) to determine how fire alters forest dynamics and species composition. Within each impuca, 50 permanent plots $(20 \times 10 \mathrm{~m})$ were established and all individuals $\geq 5 \mathrm{~cm}$ diameter at breast height (DBH) identified and measured in two censuses, the first in 2007 and the second in 2010. Unplanned fires burned 30 plots in impuca 1 and 35 in impuca 2 after the first census, which enabled the comparison between burned and unburned sites. The highest mortality ( 8.0 and 24.3\% year ${ }^{-1}$ for impuca 1 and 2) and turnover time (69 and 121.5 years) were observed in the burned sites, compared to 3.7 and 5.2\% year ${ }^{-1}$ (mortality), and 28.4 and 40.9 years (turnover), respectively, for the unburned sites. Although these seasonally flooded forested impucas are embedded in a fire-adapted savanna landscape, the impucas vegetation appears to be sensitive to fire, with burned areas having higher mortality and turnover than unburned areas. This indicates that these forest islands are potentially at risk under increasing regional fire frequency.

Keywords: impиса, tropical forest fire, mortality, recruitment, southern Amazonia, Brazil.

\section{Introduction}

The increase in global demand for grain, livestock, and biofuels driven by the rising price of oil, combined with episodic drought and fire have led to a rapid process of structural degradation and fragmentation of some Amazonian forests (Nepstad et al., 2008; Nogueira et al., 2008). Deforestation for the expansion of agriculture occurs mainly in the southern Amazonia "arc of deforestation," transitional areas of between forest and savanna (Nogueira et al., 2008). These areas have had several intense droughts over the last two decades (Marengo et al., 2011). Deforestation and drought events not only induce tree mortality (Phillips et al., 2009), but also alter the forest microclimate, for example, by allowing sun-light to penetrate canopy openings and fragment edges, drying the forest floor, rendering it more flammable, and thereby favouring the spread and recurrence of fires (Nepstad et al., 2008; Davidson et al., 2012). In addition, frequent fires modify the structure, floristic composition and functioning of plant communities in the Amazon, favouring dry-forest and savanna species which are more adapted to the presence of fire (Nepstad et al., 2008). Fire is considered one of the major threats to Amazonian forest diversity (Cochrane and Schulze, 1999; Barlow and Peres, 2004, 2008). It is therefore important to understand the effects of fire on Amazonian forests, especially in vegetation types 
representing the rapidly shrinking forest-savanna transition zone, to understand how plant community structure and composition changes through time.

The structure and dynamics of forests may be strongly influenced by natural or manmade disturbance and fire (Cochrane et al., 1999), especially due to the low resistance and resilience of forest species against such impacts (Hoffmann et al., 2000, 2003), which normally results in high mortality rates (Barlow and Peres, 2004, 2008; Balch et al., 2008). Small-scale disturbances, such as those originating from branch or tree fall, are responsible for an increase in forest structural and floristic complexity (Molino and Sabatier, 2001; Budke et al., 2010). On the other hand, large-scale disturbances such as selective logging, fragmentation and burning, may exert considerable effects on forest dynamics, causing a reduction in richness and diversity (Strasberg et al., 1995; Thonicke et al., 2001). Seasonal flooding and the saturation of soils may also affect vegetation structure and composition (Jirka et al., 2007). The effects of seasonal flooding (Guilherme et al., 2004) and fire (Nepstad et al., 2001; Balch et al., 2008) on tropical forest dynamics are known for some areas of Amazonia; however, there is currently a lack of information about how fire affects seasonally flooded forest located in the transition zone between the Amazon forest and the Cerrado biome. Moreover, the transitional forests between Cerrado and Amazon forest are very vulnerable to burning (Balch et al., 2008; Davidson et al., 2012), mainly when the occurrence of fire is related to episodes of severe droughts (Alencar et al., 2006; Balch et al., 2008; Aragão and Shimabukuro, 2010; Davidson et al., 2012).

The transition zone in Mato Grosso State in Brazil presents a wide physiognomic, structural, and floristic range because of the presence of three important biomes: Cerrado, Amazon Forest and Pantanal (Eiten, 1975, 1985; Ackerly et al., 1989; Alho, 2008). However, this region is highly threatened: almost $500.000 \mathrm{~km}^{2}$ of original Cerrado vegetation were converted into pasture through mid-2000, an area equivalent to Spain (Klink and Machado, 2005); and, according to Latrubesse et al. (2009), "no other biome in the world has been destroyed so quickly and thoroughly in human history."

In the Araguaia Plain, or Araguaia Pantanal, in the transition between Cerrado and Amazon forest, there are flooded forests regionally known as impucas (Eiten, 1985; Marimon et al., 2008) occurring in natural depressions, which favour seasonal flooding for a longer period of time. On the plains, the Araguaia River forms a vast basin and maintains the most important wetlands of Central Brazil. Threats to the biodiversity of this area are enormous (Latrubesse et al., 2009), especially as a result of recurrent fires (Marimon et al., 2008). The few studies of impucas found in the literature provide only general descriptions of the vegetation structure and are based on only one inventory (Marimon and Lima, 2001; Martins et al., 2002; Brito et al., 
2006, 2008; Marimon et al., 2008; Barbosa et al., 2011). Seasonal flooding is a factor that restrains species richness and diversity in flooded forests (Ivanauskas et al., 1997) and in impucas (or ipucas) (Brito et al., 2008; Barbosa et al., 2011), since survival in flooded environments requires species having specific physiological and morphological adaptations (Joly and Crawford, 1982; Scarano et al., 1994; Toniato et al., 1998). In addition, flood-tolerance may present an important competitive advantage (Joly and Crawford, 1982; Parolin et al., 2004), with adapted species becoming very abundant. These flood-adapted species may also be exposed to fire, which enters from the surrounding grasslands and woody savanna. Despite the regional importance of fire, it is unclear how impucas vegetation responds to fire.

The aim of this study, therefore, was to analyse and compare the woody vegetation dynamics of burned and unburned sites of two seasonally flooded impucas in north-eastern State of Mato Grosso, Brazil. We tested the hypothesis that impucas are highly susceptible to fire, which significantly alters community dynamics and vegetation species composition in a relatively short period due to a strong increase in mortality rates and a decrease in basal area and recruitment rates.

\section{Materials and methods}

\section{Study sites}

The study was carried out in two seasonally flooded forests (impucas), in the Araguaia State Park (PEA) (Impuca 1: 12॰09'4.2” S and 5049’37” W and Impuca 2: 12॰19'11.2” S and 5044'15.6” W), municipality of Novo Santo Antônio, eastern Mato Grosso State (Fig. 1). The PEA encompasses an area of 223,619 ha and is located in the flood plain formed by the confluence of the Rio das Mortes with the Rio Araguaia. It has a mean altitude of $200 \mathrm{~m}$, and is part of the Sedimentary Plain of Bananal or, according to Marimon et al. (2008), in the Araguaia Pantanal. The topography of the PEA is generally flat, and waterlogged in the rainiest months. Soils are primarily composed of Plinthosols and Gleysols, both with drainage impediments and subject to seasonal flooding (Brasil, 1994). The regional climate is the Aw type (hot tropical continental), according to Köppen's classification, characterized by a dry season between April and September, and a rainy season between October and March (Silva et al., 2008).

\section{Insert Figure 1}

The Araguaia Plain, which extends across the States of Goiás, Tocantins and eastern Mato Grosso, within the area of the Rio das Mortes and Rio Araguaia, constitutes a region with high biodiversity (Marimon and Lima, 2001), as it occurs in the transition zone between the 
Cerrado and Amazon Forest biomes (Ratter, 1987). This influences the floristic composition and creates a complex vegetation mosaic in its seasonally-flooded wide plain (Marimon and Lima, 2001; Martins et al., 2008; Barbosa et al., 2011). The region has been classified by vegetation, animal and physical specialists as an area of "extremely high biological importance" (MMA, 1999; Marimon and Lima, 2001). However, during the dry season, anthropogenic fire is becoming increasingly frequent, caused by local inhabitants, who burn the vegetation to promote the sprouting of native grasses and feed cattle, since ranching is the main activity within the park (Marimon et al., 2008).

Fires of varying sizes, intensities and frequencies occur in the Araguaia State Park (PEA) (Marimon et al., 2008). Sometimes, fire burns the surrounding matrix of the impucas (wet grasslands), but does not reach the forest (Marimon et al., 2008; Barbosa et al., 2011). Nevertheless, under conditions of low humidity and with the presence of the invasive species, Scleria sp. (Barbosa et al., 2011), the flames have penetrated the impucas and caused high tree mortality. In some cases, the impucas do not burn completely because, even in the dry season, they can be partially flooded.

\section{Vegetation inventory}

In September 2007 we established five parallel transects in each impuca, $50 \mathrm{~m}$ apart. Each transect was subdivided into plots of $20 \times 10 \mathrm{~m}$, with its length depending on the form and size of each impuca, and ranging from 50 to $120 \mathrm{~m}$ (see Fig. 1). In each transect, all living and individuals with diameter at breast height $(\mathrm{DBH}) \geq 5 \mathrm{~cm}$ were tagged identified, and their diameter measured (Barbosa et al., 2011). In 2010, all plots were re-surveyed, with all surviving and standing dead individuals re-measured. Individuals that reached $5 \mathrm{~cm}$ diameter were treated as recruits, tagged and identified. Species identifications were carried out through comparisons with the herbarium collections of the University of Mato Grosso State, Nova Xavantina Campus (Herbarium NX), the University of Brasilia (Herbarium UB), the Federal University of Mato Grosso (Herbarium UFMT), the Herbarium of Embrapa Amazonia Oriental (Herbarium IAN), and by consulting specialists. All herbarium specimens with flowers and/or fruits was incorporated into the collection of NX Herbarium.

Two fires occurred at the PEA after the first vegetation census. The first occurred in September 2007 soon after installation of the transects and reached 30 plots of impuca 1 and the second in September 2008, reaching 35 plots of impuca 2. In order to analyse the effects of the fires, the subplots were designated as either burned or unburned. 


\section{Data analysis}

Based on the data collected in the 2007 and 2010 inventories, we calculated basal area for the community and for individual species (Mueller-Dombois and Ellemberg, 1974), and from these values calculated several metrics to assess how dynamics and composition changed due to fire. First, based on the basal area, we calculated the average annual mortality rates (MO) (Equation 1),

$$
M O=\left\{1-\left[\left(A B_{0}-A B_{m}\right) / A B_{0}\right]^{1 / t}\right\} X 100
$$

where, $A B_{0}$ is initial basal area, and $A B_{\mathrm{m}}$ is dead basal area.

Recruitment (RE) (Eq. 2) (Sheil et al. 1995; 2000) was calculated as,

$$
R E=\left[1-\left(1-A B_{r} / A B_{t}\right)^{1 / t}\right] \times 100 \text { (Eq. 2) }
$$

where, $A B_{\mathrm{r}}$ is recruits basal area, $A B_{\mathrm{t}}$ is final basal area, and $t$ is the elapse of time in years.

Loss (L) (Eq. 3) and gain (G) (Eq. 4) in basal area (Guimarães et al., 2008), in addition to the basal area turnover time (TUR) (Eq. 5) (Korning and Balslev, 1994), were calculated as,

$$
\begin{aligned}
& L=\left\{1-\left[\left(A B_{0}-A B_{m}-A B_{d}\right) / A B_{0}\right]^{1 / t}\right\} x 100 \text { (Eq. 3) } \\
& G=\left\{1-\left[1-\left(A B_{r}+A B_{g}\right) / A B_{t}\right]^{1 / t}\right\} x 100(\text { Eq. 4) } \\
& T U R=\left(T_{1 / 2}+T_{2}\right) / 2 \text { (Eq. 5) }
\end{aligned}
$$

where, $A B_{0}$ is initial basal area, $A B_{\mathrm{m}}$ is dead basal area, $A B_{\mathrm{d}}$ is basal area decrement, $A B_{\mathrm{r}}$ is recruits basal area, $A B_{\mathrm{g}}$ is basal area increment, $A B_{\mathrm{t}}$ is final basal area, $t$ is the elapsed time in years, $T_{1 / 2}$ is half-life time, and $T_{2}$ is duplication time.

Based on the individuals occurring in both inventories, we calculated the average annual mortality rates (Mo) (Eq. 6) and recruitment rates (Re) (Eq. 7) (Sheil et al., 1995, 2000),

$$
\begin{aligned}
& M o=\left\{1-\left[\left(N_{0}-N_{m}\right) / N_{0}\right]^{1 / t}\right\} x 100 \text { (Eq. 6) } \\
& \operatorname{Re}=\left[1-\left(1-N_{r} / N_{t}\right)^{1 / t}\right] x 100 \text { (Eq. 7) }
\end{aligned}
$$

where, $N_{0}$ is initial number of individuals, $N_{\mathrm{m}}$ is the number of dead individuals, $N_{\mathrm{r}}$ is the number of recruits, $N_{\mathrm{t}}$ is the final number of individuals, and $t$ is the elapse of time in years;

And, the half-life time $\left(\mathrm{T}_{1 / 2}\right)$ (Eq. 8), i.e., the time necessary for a given population to decrease by $50 \%$ of its individuals from its current mortality rate, duplication time $\left(\mathrm{T}_{2}\right)$ (Eq. 9), i.e., the 
time necessary for a given population to duplicate its individuals from its current recruitment rate (Lieberman et al., 1985),

$$
\begin{aligned}
& T_{1 / 2}=\operatorname{Ln}_{(1 / 2)} / \operatorname{Ln}\left(\left[\left(N_{0}-N_{m}\right) / N_{0}\right]^{1 / t}\right)(\text { Eq. } 8) \\
& T_{2}=\operatorname{Ln} n_{(2)} / \operatorname{Ln}\left(\left[\left(N_{0}+N_{r}\right) / N_{0}\right]^{1 / t}\right)(\text { Eq. 9) }
\end{aligned}
$$

stability (E) (Eq. 10), i.e., the values nearest to zero indicate that the community would be more stable, and turnover time (TUR) (Eq. 11), i.e., how much higher the turnover rate, higher mortality rates and/or recruitment (Korning and Balslev, 1994).

$$
\begin{aligned}
& E=\left(T_{1 / 2}-T_{2}\right)(\text { Eq. 10) } \\
& T U R=\left(\left(T_{1 / 2}+T_{2}\right) / 2\right)(\text { Eq. 11) }
\end{aligned}
$$

where, $\mathrm{Ln}$ is the natural logarithm, $N_{0}$ is the initial number of individuals, $N_{\mathrm{m}}$ is the number of dead individuals, $N_{\mathrm{r}}$ is the number of recruits, $t$ is the elapse of time in years, $T_{1 / 2}$ is the half-life time, and $T_{2}$ is the duplication time.

In addition, for the ten main species in terms of importance value (VI sensu Curtis and McIntosh, 1950) measured in the 2007 inventory, we calculated the average annual mortality and recruitment rates, and the half-life and duplication times based on the number of individuals between 2007 and 2010. For the same period, and based on the individual basal area, we calculated the average annual rates of loss (Eq. 3) and gain in basal area (Eq. 4).

The average annual rates of mortality, recruitment, loss, gain and turnover (based on the number of individuals and the individual basal area), and the half-life and duplication times for each plot were used to compare the dynamics of burned and unburned sites within each impuca. For these comparisons, we used the non-parametric analysis of Mann-Whitney (Sokal and Rohlf, 1995). Histograms were plotted of individual and basal area distribution in diameter classes, where the equation for the calculation of the class intervals was based on Spiegel (1976). For each diameter classes. To compare the distributions of both inventories within the same sites of each impuca, we performed Kolmogorov-Smirnov tests. To determine the relationship between mortality (number of dead individuals and their basal area) and the diameter classes, we used simple linear regressions. All analyses were conducted using the R software statistical platform (R Development Core Team, 2011).

\section{Results}


Between 2007 and 2010, there was a reduction in basal area and absolute density of individuals in both burned and unburned sites of the impucas (Table 1). For the unburned sites, there was little reduction in impuca 1 (2.8\% on a basal area-basis), while in impuca 2 the reduction was $8 \%$, for a basal area-basis. In the burned sites, the reduction in basal area was greater for both impuca 1 (10.1\%, basal area-basis) and for impuca 2 (39.3\%, for basal areabasis) (Table 1). The higher basal area loss due to mortality compared to basal area gain due to recruitment resulted in an average net loss of basal area for all of the sites (Table 2).

\section{Insert Table 1}

In comparing the effect of fire, there were high average annual mortality rates $\left(8 \%\right.$ year ${ }^{-1}$ in impuca 1 and 24.3 in impuca 2) compared to recruitment in the burned sites $\left(0.68 \% \mathrm{yr}^{-1}\right.$ in impuca 1 and 0.66 in impuca 2), and also compared to mortality in the unburned sites of both impucas (Table 2). Due to the high mortality rates observed in the burned sites, there was a significant difference with respect to basal area loss between burned and unburned sites in both impucas (Table 2). For the gain rate of basal area, there was only a significant difference between the burned and unburned sites of impuca 1, with a greater gain for the unburned sites. In contrast, despite the burned sites of impuca 2 having higher gain rates of basal area than the unburned sites, their rate of loss of individuals was nearly four times higher, compared to unburned sites (Table 2). The recruitment rates of all sites (burned and unburned) were low (between $0.7 \% \mathrm{yr}^{-1}$ in impuca 1 and $2 \% \mathrm{yr}^{-1}$ in impuca 2) (Table 2). Even the unburned sites had lower recruitment than mortality rates. The individual- and basal area-based mortality rates in the burned sites were higher than the rates observed in the unburned sites of both impucas. In contrast, the recruitment rates in the burned sites were higher than in the unburned sites of both impucas (Tables 1 and 2).

\section{Insert Table 2}

For all studied sites (burned and unburned), the values of half-life time were lower than the duplication time, on both an individual- and basal area-basis (Table 2). The values turnover time, on both an individual- and basal area-basis, were higher for the burned than for the unburned sites in both impucas (Table 2). There was a reduction in the number of individuals in most of the diameter classes after fire occurrence, and changes within and between the diameter classes (Fig. 3). The distribution of individuals among diameter classes did not differ between inventories for unburned sites $\left(\mathrm{KS}, \chi^{2}=0.0319, P>0.05\right)$ and burned sites $\left(\mathrm{KS}, \chi^{2}=0.0537\right.$, $p>0.05$ ) for impuca 1 and unburned sites of impuca $2\left(\mathrm{KS}, \chi^{2}=0.0301, P>0.05\right)$. There was only a reduction in the frequency of individuals of burned sites in impuca 2 (KS, $\chi^{2}=0.1818, P$ $<0.001)$. 
For mortality, on an individual-basis, there was a negative relationship with increasing diameter class for the burned sites of impuca $1\left(\mathrm{R}^{2}=0.79 ; \mathrm{F}=27.42 ; P=0.002\right)$ and impuca 2 $\left(\mathrm{R}^{2}=0.90 ; \mathrm{F}=66.76 ; P=0.001\right)($ Fig. $4 \mathrm{~A}, \mathrm{~B})$. Mortality on a basal area-basis was negatively related with diameter class only for the burned sites of impuca $2\left(\mathrm{R}^{2}=0.60 ; \mathrm{F}=11.54 ; P=\right.$ $0.01)$, with no significant relationship in impuca $1\left(\mathrm{R}^{2}=0.17 ; \mathrm{F}=2.43 ; P=0.16\right)$ (Fig. $\left.4 \mathrm{C}, \mathrm{D}\right)$. Even with most of the dead individuals concentrated in the smaller diameter classes (Fig. 4), the highest mortality rates were observed for the larger diameter classes for the unburned sites of impuca 1 (>35 to $40 \mathrm{~cm}$ ) and impuca $2(>30$ to $35 \mathrm{~cm}$ ) (Fig. 2A and C), while for the burned sites of these impucas, the highest mortality rates were observed in the first diameter class 5 to $10 \mathrm{~cm}$ (Fig. 2A, C). The highest recruitment rates, on both an individual- and basal area-basis, were found in the smallest diameter classes of the burned and unburned sites of both impucas (Fig. 2B, D). Considering both individual- and basal area-basis, the rates of change were negative for most of the classes of all the burned and unburned sites, except for the larger diameter classes (Fig. 4). mortality than recruitment rates. Only three species in the unburned sites of impuca 1 had recruitment rates equal or higher than mortality rates (Licania apetala, Ormosia excelsa and Diospyros poeppigiana) (Table 3). For basal area in the burned sites, all species had higher rates of loss than gain. However, in the unburned sites, the rates of basal area gain were higher than basal area loss for six species of impuca 1 (L. apetala, Mabea paniculata, O. excelsa, Calophyllum brasiliense, Diospyros tetrandra, and D. poeppigiana) and three species of impuca 2 (Ternstroemia candolleana, Symmeria paniculata, and Roupala montana) (Table 3).

\section{Discussion}

The results of this study, the first of our knowledge examining the response of impucas fire, indicate that these seasonally flooded forests are generally not fire-resistant. Mortality rates and basal area loss were high, while recruitment was outpaced by mortality. Some species have adaptations to fire, e.g. thicker bark (Calophyllum brasiliense, Licania apetala, Roupala montana and Vochysia divergens). This unique vegetation type in the Cerrado-Amazon forest 
transition appears to be highly dynamic (both unburned and burned plots), responding to the dual stress of seasonally saturated soil environment of the roots and infrequent, but over the years increasing fire events.

\section{Community-level patterns}

The mortality rates from the unburned impucas of our study were higher than those in an experimental study in a burned Amazonian transition forest (4.8\% per year) (Balch et al. 2008). Furthermore, annual mortality rates in the burned impucas of our study were two to six times this rate. Mortality rates commonly reported for protected tropical forests are approximately 1 to $2 \%$ per year (Condit et al., 1995; Stephenson and van Mantgem, 2005), much lower than the rates observed for the burned and unburned impucas sites, suggesting that unburned sites may also be affected by additional factors with negative influence (e.g. drought). On the other hand, the high mortality rates measured in the burned sites of our study show that fire has a negative effect on impuсa vegetation and that areas that are seasonally inundated are still susceptible to fire intrusion despite the long period with saturated soil and likely proximity of the water table to the surface (Brito et al., 2008).

The high number of dead individuals and reduced basal area in burned compared to unburned sites is consistent with our hypothesis that the impucas are highly susceptible to fire. However, since a reduction in individual density and in basal area was also measured in the unburned forest, it is also possible that the 2010 drought-- which reduced rainfall in this region compared to the long-term average (Marengo et al., 2011)-- may have been a factor influencing negatively the sites. The reduction in individuals in the unburned sites in our study may also be a result in a time-lag in mortality from previous fires, since some impucas in the region may have previously burned (Barbosa et al., 2011). It is also important to emphasise that the losses due to fire may go beyond the direct effects observed immediately after the burning, since fire increases the probability and susceptibility to future burning (Cochrane et al., 1999).

\section{Effects of tree size}

We found contrasting patterns of tree mortality by diameter class, with the larger classes having the highest mortality rates in unburned plots, but the smallest classes having the highest mortality rates in burned plots. Losses from the smaller size-classes may affect future regeneration, while losses from the larger diameter classes results in a large reduction in basal area and may affect seed sources, and increase irradiance. In forests, the highest numbers of dead 
individuals are commonly measured in the smaller diameter classes. This pattern could be attributed to the low capacity of smaller individuals to compete with canopy trees (Felfili, 1995), and higher vulnerability to disturbance, such as fire. In the present study, this pattern was observed in both the burned and unburned sites. Therefore, it is probable that the higher mortality in the smaller size classes is related to the higher proportion of individuals in these smaller size classes (Fig. 2), and their low tolerance to fire (Hoffmann and Solbrig, 2003; Medeiros and Miranda, 2005). Barlow et al. (2003) reported significant loss of individuals in the Amazon Forest after fire disturbance, and observed that even large trees, which seem to be initially fire resist, died nearly three years after fire occurrence. In the unburned sites of the impucas of our study, the high mortality rates observed in the larger diameter classes may be related to the presence of older, senescent individuals or a delayed response to fire occurrence before 2007 (Herson Lima, PEA Administrator, pers. communication). However, the low number of individuals in the larger classes could be overestimating the mortality rates, because of the high stochasticity in the data due to small sample sizes. Sampling and evaluation of the plot data for a longer period will give a still more realistic picture of the effects of fire on individuals with different diameters.

Fire also appears to have exerted a strong effect on the smaller individuals in the burned sites and did reduce recruitment. Generally, recruitment rates exhibited by the vegetation in the impuca forests were low, when compared to other forest studies where values ranged from 3.5 to 4.5\% year $^{-1}$ (Gomes et al., 2003; Paiva et al., 2007; Silva and Araújo, 2009). It is important to note that even the unburned sites had on average lower recruitment rates than those reported for other forests.

\section{Populations}

Species that had higher recruitment and gain rates than mortality and basal area loss, such as Calophyllum brasiliense and Symmeria paniculata, have thicker bark (Barbosa et al., 2011) and were distributed in a more central position in the forests, more distant from the border and from the fire, respectively. The liana Combretum laxum had the highest mortality rate among the burned and unburned sites for species of impuca 2, as well as high basal area loss relative to gain for the burned sites, consistent with the idea that lianas are very sensitive to fire (Gerwing, 2002; Nepstad et al., 2007; Balch et al., 2011).

\section{Climate}


In a flooded forest plain in the Peruvian Amazon, Nebel et al. (2001) reported low mortality rates (between 2.2 and 3.2\% year-1), and the recruitment rates (between 3.0 and $4.6 \%$ year $^{-1}$ ) were higher than the mortality rates. In contrast, in the present study, even the unburned sites had recruitment rates lower than mortality rates. One explanation for the differences between the results of Nebel et al. (2001) and ours may be that their sites are located in a more central area of the Amazonian biome and are under more stable climatic conditions. The impucas of our study, besides being under a seasonal climate with lower annual rainfall, are surrounded by grassland and herbaceous fields (Martins et al., 2002, 2006; Marimon et al., 2008; Barbosa et al., 2011) favouring the development and passage of fire into the forest during the dry season, especially at the margins of the stands (Oliveira-Filho et al., 1997, 2007). Therefore, it is likely that local climatic conditions, including drought, and the border effect may have contributed to the observed difference in mortality and recruitment.

\section{Root system}

The soils of the forests of our study have a thick layer of organic matter and are streaked by a mesh of fine roots (Barbosa et al., 2011). During the month when burnings occurred (September), the litter layer and the mesh of roots that covers the soil became dry and susceptible to fire. After fire had entered the forests, root systems of several trees were completely burned, resulting in the trunks of some large trees remaining suspended in the air supported by their canopies locked into those of neighbouring trees. This observation reinforces other studies indicating that creeping fires on the forest floor causes major impacts in Amazonian forests, and in the case of our study, higher mortality rates.

\section{Factors causing instability in Amazonian transition forests}

Disturbances such as flooding, burning, droughts, and human activity may cause forest instability. Alencar et al. (2004) emphasized that the Amazonian transitional forests, besides suffering strong deforestation pressure (Nogueira et al., 2008), have been suffering major damage caused by fire. This is partially a result of having a more open canopy structure compared to the dense forests of central Amazonia, making transitional forests more prone to drying, and increasing vulnerability to fire. Moreover, several studies have reported disequilibrium between mortality and recruitment in seasonal forests (Appolinário et al., 2005; Enquist and Enquist, 2011) and gallery forests (Braga and Rezende, 2007; Miguel et al., 2011). Additionally, the ground fires are passing rather quickly a certain location so that extreme temperatures are measured there only for few minutes (e.g. Northern Conifer Forests). Whereas, 
crown-fires remain for a longer period of time at a particular site, thus increasing the extreme temperature situation and making inefficient all plant adaptations against quickly passing fire fronts, as observed in the impucas. Although in the current study it appears that fire and/or drought may be the main causative agent of this disequilibrium, natural flooding, or changes in the flood regime must also be evaluated as a potential driver in future studies, since some studies have reported that the flood period is one of the most important factors that influence growth, distribution and richness of species in flooded forests in the Amazon (Wittmann et al., 2002, 2004).

\section{Turnover}

The high turnover time, duplication time, as well as the low half-life time observed in the burned sites reinforce that effects of fire on the impuca communities are quite deleterious, as they reduce the number of individuals by half within a short period of time $(<7$ years), so that it would take substantial time ( $>130$ years) to duplicate the number of individuals, if the high rates of mortality and low rates of recruitment found in this study continued. For some forests not subjected to seasonal flooding, there is a reported pattern of balance between half-life and duplication times (Oliveira-Filho et al., 1997; Paiva et al., 2007; Silva and Araújo, 2009). The disequilibrium between such parameters reported in our study may be attributed to the imbalance between the mortality and recruitment rates. In the burned sites, fire may have been the keyfactor for this increase in disequilibrium, since in these sites we observed low recruitment and high mortality of individuals. A forest community, in order to be balanced, requires stability in mortality, recruitment, half-life and duplication times (Korning and Balslev, 1994). The lack of stability in these rates raises concerns about the maintenance of these forests in the short and medium term.

The values of half-life time of the unburned sites were similar to the 17.2 and 16.9 years in a semi-deciduous forest of Minas Gerais State, Brazil, reported by Paiva et al. (2007) and Silva and Araújo (2009). In a disturbed forest in the Peruvian Amazon, Nebel et al. (2001) reported higher half-life times (between 22 and 32 years) and lower duplication times (between 16 and 24 years). Other studies in Amazonia reported higher half-life times (between 24 and 99 years) and lower duplication times (between 25 and 86 years) (Uhl et al., 1988; Rankin-deMérona et al., 1990; Gentry and Terborgh, 1990; Phillips et al., 1994; Phillips and Gentry, 1994) compared to those observed in the burned impuca sites, emphasizing the high rates of disturbance observed in both forests of our study. The turnover times of our study were high when compared with those non-seasonally flooded forests (Oliveira-Filho et al., 1997; Paiva et 
al., 2007; Silva and Araújo, 2009), indicating that impucas, both burned and unburned, are extremely dynamic compared to other forests.

\section{Conclusions}

Here we provided new information on the impacts of fire on seasonally flooded forests of the Cerrado-Amazon Forest transition. However, due to spatial and temporal limitations of our study, care should be taken when extrapolating our findings to other regions of Amazonia. Future studies should increase the number of sampling units, the monitoring period, and extend sampling to other physiognomies in the Amazon transitional zone. In summary, our results support the hypothesis that greater structural changes occurred in the burned sites of both forests. The high rates of mortality and loss in basal area and the relatively low rates of recruitment and gain in basal area observed in the burned sites may be attributed to fire entering the forests. However, the high level of dynamism observed for the unburned sites indicate that these forests are also being affected by other factors in addition to fire. Humans have been responsible for the increased frequency of fire in impucas, and if these forests are to remain, it may be necessary to adopt fire prevention measures. Long-term studies that also examine the effects of flooding and drought on forest dynamism and productivity of impucas will help to separate the effect of fire from climatic drivers of productivity in this unique vegetation community of the Amazon Forest - Cerrado Biome transition.

\section{Acknowledgements}

We thank the Mato Grosso State Secretary for the Environment (SEMA-MT) for allowing the study in the Araguaia State Park, to Claudinei O. Santos, Paulo S. Morandi, Lucélia S. Silva, Fernando Elias and Danielle C. F. Barbosa, for their contribution in field inventories and to Fabrício A. Leal for the map of the study area. LM, LG, EAO and HAM were supported by CAPES studentship. TRF was supported by the NERC-funded project AMAZONICA and TROBIT, and the Gordon and Betty Moore Foundation by a grant to RAINFOR. This study was supported by a grant from the Mato Grosso State Research Support Foundation (FAPEMAT) and from the Program of Academic Cooperation (PROCAD/CAPES). We are grateful to Tim R. 
Baker and James A. Ratter for have provided insightful suggestions on earlier versions of the manuscript.

\section{References}

Ackerly, D.D., Thomas, W.W., Ferreira, C.A.C., Pirani, J.R., 1989. The forest-cerrado transition zone in southern Amazonia: results of the 1985 projeto flora amazonica expedition to Mato Grosso. Brittonia 41, 113-128.

Alencar, A., Nepstad, D., Diaz, M.D.C.V., 2006. Forest understory fire in the Brazilian Amazon in enso and non-enso years: area burned and committed carbon emissions. Earth Interact. 10, $1-17$.

Alencar, A., Nepstad, D., McGrath, D., Moutinho, P., Pacheco, P., Diaz, M.D.C.V., SoaresFilho, B., 2004. Desmatamento na Amazônia; indo além da "emergência crônica". Instituto de Pesquisa Ambiental da Amazônia, Belém.

Alho, C.J.R., 2008. Biodiversity of the Pantanal: response to seasonal flooding regime and to environmental degradation. Braz. J. Biol. 68, 957-966.

Appolinário, V., Oliveira-Filho, A.T., Guilherme, F.A.G., 2005. Tree population and community dynamics in a Brazilian tropical semideciduous forest. Rev. Bras. Bot. 28, 347-360.

Aragão, L.E., Shimabukuro, Y.E., 2010. The incidence of fire in Amazonian forests with implications for REDD. Science, 328, 1275-1278.

Balch, J.K., Nepstad, D., Brando, P.M., Curran, L., Portela, O., Carvalho, O., Lefebvre, P., 2008. Negative fire feedback in a transitional forest of southeastern Amazonia. Glob. Change Biol. $14,2276-2287$.

Balch, J.K., Nepstad, D., Curran, L.M., Brando, P.M., Portela, O., Guilherme, P., ReuningScherera, J.D., Carvalho Junior, O., 2011. Size, species, and fire behavior predict tree and liana mortality from experimental burns in the Brazilian Amazon. Forest Ecol. Manag. 261, 68-77.

Barbosa, D.C.F., Marimon, B.S., Lenza, E., Marimon-Junior, B.H., Oliveira, E.A., Maracahipes, L., 2011. Estrutura da vegetação lenhosa em dois fragmentos naturais de florestas 
inundáveis (impucas) no Parque Estadual do Araguaia, Mato Grosso. Rev. Árvore 25, 457471.

Barlow, J., Peres, C.A., 2004. Ecological responses to El Niño-induced surface fires in central Brazilian Amazonia: management implications for flammable tropical forests. Philos. T. R. Soc. B. $359,367-380$.

Barlow, J., Peres, C.A., 2008. Fire-mediated dieback and compositional cascade in an Amazonian forest. Philos. T. R. Soc. B. 363, 1787-1794.

Barlow, J., Peres, C.A., Logan, B.O., Haugaasen, T., 2003. Large tree mortality and the decline of forest biomass following Amazonian wildfires. Ecol. Lett. 6, 6-8.

Braga, F.M.S., Rezende, A.V., 2007. Dinâmica da vegetação arbórea da mata de galeria do Catetinho, Brasília-DF. Cerne 13, 138-148.

Brasil. 1994. Ministério do Meio Ambiente e da Amazônia Legal. IBAMA. Plano de ação emergencial para o Parque Nacional do Araguaia. Documento de Informações Básicas, Brasília.

Brito, E.R., Martins, S.V., Oliveira-Filho, A.T., Silva, E., Silva, A.F., 2006. Estrutura fitossociológica de um fragmento natural de floresta inundável em área de orizicultura irrigada, município de Lagoa da Confusão, Tocantins. Rev. Árvore 30, 829-836.

Brito, E.R., Martins, S.V., Oliveira-Filho, A.T., Silva, E., Silva, A.F., 2008. Estrutura fitossociológica de um fragmento natural de floresta inundável em área de Campo Sujo, Lagoa da Confusão, Tocantins. Acta Amazon. 38, 379-386.

Budke, J.C., Jarenkow, J.A., Oliveira-Filho, A.T., 2010. Intermediary disturbance increases tree diversity in riverine forest of southern Brazil. Biodivers. Conserv. 19, 2371-2387.

Cochrane, M.A., Schulze, M.D., 1999. Fire as a recurrent event in tropical forests of the eastern Amazon: effects on forest structure, biomass, and species composition. Biotropica 31, 2-16.

Cochrane, M.A., Alencar, A., Schulze, M.D., Souza Jr, C.M., Nepstad, D.C., Lefebvre, P., Davidson, E.A., 1999. Positive feedbacks in the fire dynamic of closed canopy tropical forests. Science 284, 1832-1835.

Condit, R., Hubbell, S.P., Foster, R.B., 1995. Mortality rates of 205 Neotropical tree and shrub species and the impact of a severe drought. Ecol. Monogr. 65, 419-439.

Curtis, J.T., McIntosh, R.P., 1950. The interrelations of certain analytic and synthetic phytosociological characteres. Ecology:434-455.

Davidson, E.A., Araújo, A.C., Artaxo, P., Balch, J.K., Brown, I.F., Bustamante, M.M.C., Coe, M.T., DeFreies, R.S., Keller, M., Longo, M., Munger, J.W., Schroeder, W., Soares-Filho, 
B.S., Souza Jr., C.M., Wofsy, S.C., 2012. The Amazon basin in transition. Nature 481, 321328.

Eiten, G., 1975. The vegetation of the Serra do Roncador. Biotropica 7, 112-135.

Eiten, G., 1985. Vegetation near Santa Teresinha, NE Mato Grosso. Acta Amazon. 3-4, 275-301.

Enquist, B.J., Enquist, C.A.F., 2011. Long-term change within a Neotropical forest: assessing differential functional and floristic responses to disturbance and drought. Glob. Change Biol. 17, 1408-1424.

Felfili, J.M., 1995. Growth, recruitment and mortality in the Gama gallery forest in central over a six-year period (1985-199). J. Trop. Ecol. 11, 67-83.

Gentry, A.H., Terborgh, J., 1990. Composition and dynamics of the Cocha Cashu meture floodplain forest. In: Gentry, A.H. (Ed.), Four neotropical rainforests. Yale University Press, New Haven, pp. 542-563.

Gerwing, J.J., 2002. Degradation of forests through logging and fire in the eastern Brazilian Amazon. Forest Ecol. Manag. 157, 131-141.

Gomes, E.P.C., Mantovani, W., Kageyama, P.Y., 2003. Mortality and recruitment of trees in a secondary montane rain forest in southeastern Brazil. Braz. J. Biol. 63, 47-60.

Guilherme, F.A.G., Oliveira-Filho, A.T., Appolinário, V., Bearzoti, E., 2004. Effects of flooding regime and woody bamboos on tree community dynamics in a section of tropical semideciduous forest in South-Eastern Brazil. Plant Ecol. 174, 19-36.

Guimarães, J.C.C., van den Berg, E., Castro, G.C., Machado, E.L.M., Oliveira-Filho, A.T., 2008. Dinâmica do componente arbustivo-arbóreo de uma floresta de galeria aluvial no planalto de Poços de Caldas, MG, Brasil. Rev. Bras. Bot. 31, 621-632.

Hoffmann, W.A., 2000. Post-establishment seedling success in the Brazilian cerrado: a comparison of savanna and forest species. Biotropica 32, 62-69.

Hoffmann, W.A., Orthen, B., Nascimento, P.K.V., 2003. Comparative fire ecology of tropical savanna and forest trees. Funct. Ecol. 17, 720-726.

Hoffmann, W.A., Solbrig, O.T., 2003. The role of topkill in the differential response of savanna woody species to fire. Forest Ecol. Manag. 180, 273-286.

Ivanauskas, N.M., Rodrigues, R.R., Nave, A.G., 1997. Aspectos ecológicos de um trecho de floresta de brejo em Itatinga, SP: florística, fitossociologia e seletividade de espécies. R. Bras. Bioci. 20, 139-153.

Jirka, S., McDonald, A.J., Johnson, M.S., Feldpausch, T.R., Couto, E.G., Riha, S.J., 2007. Relationships between soil hydrology and forest structure and composition in the southern Brazilian Amazon. J. Veg. Sci. 18, 183-194. 
Joly, C.A., Crawford, R.M.M., 1982. Variation in tolerance and metabolic responses to flooding in some tropical trees. J. Exp. Bot. 33, 799-809.

Klink, C.A., Machado, R.B., 2005. Conservation of the Brazilian Cerrado. Conserv. Biol. 19, 707-713.

Korning, J., Balslev, H., 1994. Growth and mortality of trees in amazonian tropical rain forest in Ecuador. J. Veg. Sci. 5, 77-86.

Latrubesse, E.M., Amsler, M., Morais, M., Aquino, S., 2009. The geomorphological response of a large pristine alluvial river to tremendous deforestation in the South American Tropics: the case of the Araguaia River. Geomorpholohy 113:239-252

Lieberman, D., Lieberman, M., Peralta, R., Hartshorn, G.S., 1985. Mortality patterns and stand turnover rates in a Wet Tropical forest in a Costa Rica. J. Ecol. 73, 915-924.

Marengo, J.A., Tomasella, J., Alves, L.M., Soares, W.R., Rodriguez, D.A., 2011. The drought of 2010 in the context of historical droughts in the Amazon region. Geophys. Res. Lett. 38, L12703, 10.1029/2011g1047436.

Marimon, B.S., Lima, E.S., 2001. Caracterização fitofisionômica e levantamento florístico preliminar no Pantanal dos rios Mortes-Araguaia, Cocalinho, Mato Grosso, Brasil. Acta Bot. Bras. 15, 213-229.

Marimon, B.S., Marimon-Junior, B.H., Lima, H.S., Jancoski, H.S., Franczak, D.D., Mews, H.A., Moresco, M.C., 2008. Pantanal do Araguaia - ambiente e povo: guia de ecoturismo. Unemat, Cáceres.

Martins, A.K.E., Schaefer, C.E.G.R., Silva, E., Soares, V.P., Corrêa, G.R., Mendonça, B.A.F., 2006. Diagnóstico ambiental no contexto da paisagem de fragmentos florestais naturais "ipucas" no município de lagoa da confusão, Tocantins. Rev. Árvore 30, 297-310.

Martins, I.C.M., Soares, V.P., Silva, E., Brites, R.S., 2002. Diagnóstico ambiental no contexto da paisagem de fragmentos florestais naturais "ipucas" no município de lagoa da confusão, Tocantins. Rev. Árvore 26, 299-309.

Martins, S.V., Brito, E.R., Oliveira-Filho, A.T., Silva, A.F., Silva, E., 2008. Floristic composition of two wetland forests in Araguaian Plain, State of Tocantins, Brazil, and comparison with other areas. Rev. Árvore 32, 129-141.

Medeiros, M.B., Miranda, H.S., 2005. Mortalidade pós-fogo em espécies lenhosas de campo sujo submetido a três queimadas prescritas anuais. Acta Bot. Bras. 19, 493-500.

Miguel, A., Marimon, B.S., Oliveira, E.A., Maracahipes, L., Marimon-Junior, B.H., 2011. Dinâmica da comunidade lenhosa de uma floresta de galeria na transição Cerrado-Floresta 
Amazônica no leste de Mato Grosso, em um período de sete anos (1999 a 2006). Biota Neotrop. 11, 53-61.

MMA-Ministério do Meio Ambiente. 1999. Ações prioritárias para a conservação da biodiversidade do Cerrado e Pantanal. Brasília (Brazil): FUNATURA/Conservation International/UnB, Brasília.

Molino, J.F., Sabatier, D., 2001. Tree diversity in tropical rain forests: a validation of the intermediate disturbance hypothesis. Science 294, 1702-1704.

Mueller-Dombois, D., Ellemberg, H., 1974. Aims and Methods in Vegetation Ecology. Wiley, New York.

Nebel, G., Kvist, L.P., Vanclay, J.K., Vidaurre, H., 2001. Forest dynamics in flood plain forests in the Peruvian Amazon: effects of disturbance and implications for management. Forest Ecol. Manag. 150, 79-92.

Nepstad, D., Carvalho, G.O., Barros, A.C., Alencar, A., Capobianco, J.P., Bishop, J., Moutinho, P., Lefebvre, P.A., Silva, U.L., Prins, E., 2001. Road paving, fire regime feedbacks, and the future of Amazon forests. Forest Ecol. Manag. 154, 395-407.

Nepstad, D., Tohver, I.M., Ray, D., Moutinho, P., Cardinot, G., 2007. Mortality of large trees and lianas following experimental drought in an Amazon forest. Ecology 88, 2259-2269.

Nepstad, D.C., Stickler, C.M., Soares-Filho, B., Merry, F., 2008. Interactions among Amazon land use, forests and climate: propects for a near-term forest tipping point. Philos. T. R. Soc. B. $363,1737-1746$.

Nogueira, E.M., Nelson, B.W., Fearnside, P.M., França, M.B., Oliveira, A.C.A., 2008. Tree height in Brazil's 'arc of deforestation': shorter trees in south and southwest Amazonia imply lower biomass. Forest Ecol. Manag. 255, 2963-2972.

Oliveira-Filho, A.T., Carvalho, W.A.C., Machado, E.L.M., Higuchi, P., Appolinário, V., Castro, G.C., Silva, A.C., Santos, R.M., Borges, L.F., Corrêa, B.S., Alves, J.M., 2007. Dinâmica da comunidade e populações arbóreas da borda e interior de um remanescente florestal na Serra da Mantiqueira, Minas Gerais, em um intervalo de cinco anos (1999-2004). Rev. Bras. Bot. 30,149-161.

Oliveira-Filho, A.T., Mello, J.M., Scolforo, J.R.S., 1997. Effects of past disturbance and edges on tree community structure and dynamics within a fragment of tropical semideciduous forest in southeastern Brazil over a five-year period (1987-1992). Plant Ecol. 131, 45-66.

Paiva, L.V., Araújo, G.M., Pedroni, F., 2007. Structure and dynamics of a woody plant community of a tropical semi-deciduous seasonal forest in the "Estação Ecológica do Panga", municipality of Uberlândia, Minas Gerais, Brazil. Rev. Bras. Bot. 30, 365-373. 
Parolin, P., Ferreira, L.V., Albernaz, A.L.K.M., Almeida, S.S., 2004. Tree species distribution in Várzea Forests of Brazilian Amazonia. Folia Geobot. 39, 371-383.

Phillips, O.L., Gentry, A.H., 1994. Increasing turnover through time in tropical forests. Science 262, 954-958.

Phillips, O.L., Hall, P., Gentry, A.H., Swayer, S.A., Vásquez, R., 1994. Dynamics and species richness of tropical rain forests. P. Natl. Acad. Sci. USA 91, 2805-2809.

Phillips, O.L., Aragão, L.E.O.C., Lewis, S.L., Fisher, J.B., López-González, G., Malhi, Y., Monteagudo, A., Peacock, J., Quesada, C.A., van der Heijden, G., et al., 2009. Drought sensitivity of the Amazon rainforest. Science 323, 1344-1347.

R Development Core Team, 2011. R: a language and environment for statistical computing. R Foundation for Statistical Computing, Vienna.

Rankin-de-Mérona, J.M., Hutchings, H., Lovejoy, T.E., 1990. Tree mortality and recruitment over a five-year period in undisturbed upland rainforest of the Central Amazon. In: Gentry, A.H. (Ed.), Four neotropical rainforests. Yale University Press, New Haven, pp. 573-584.

Ratter, J.A., 1987. Notes on the vegetation of the Parque Nacional do Araguaia Brazil. Notes R. Bot. Gard. Edinb. 44, 311-342.

Scarano, F.R., Cattânio, J.H., Crawford, R.M.M., 1994. Root carbohydrate storage in young samplings of an Amazonian tidal várzea forest before the onset of wet season. Acta Bot. Bras. 8, 129-139.

Sheil, D., Burslem, D.F.R.P., Alder, D., 1995. The interpretation and misinterpretation of mortality rate measures. J. Ecol. 83, 331-333.

Sheil, D., Jennings, S., Savill, P., 2000. Long-term permanent plot observations of vegetation dynamics in Budongo, a Ugandan rain forest. J. Trop. Ecol. 16, 765-800.

Silva, F.A.M., Assad, E.D., Evangelista, B.A., 2008. Caracterização climática do bioma cerrado. In: Sano, S.M., Almeida, S.P., Ribeiro, J.F. (Eds.), Cerrado: ecologia e flora. Embrapa Cerrados, Brasília, pp. 69-88.

Silva, M.R., Araújo, G.M., 2009. Dinâmica da comunidade arbórea de uma floresta semidecidual em Uberlândia, MG, Brasil. Acta Bot. Bras. 23, 49-56.

Sokal, R.R., Rohlf, F.G., 1995. Biometry. W.H. Freeman and Company, New York.

Spiegel, M.P., 1976. Estatística. McGraw-Hill, São Paulo.

Stephenson, N.L., van Mantgem, P.J., 2005. Forest turnover rates follow global and regional patterns of productivity. Ecol. Lett. 8, 524-531.

Strasberg, D., Faloya, V., Lepart, J., 1995. Patterns of tree mortality in an island tropical rainforest subjected to recurrent windstorms. Acta Oecol. 16, 237-248. 
671 Thonicke, K., Venevsky, S., Sitch, S., Gramer, W., 2001. The role of fire disturbance for global 672 vegetation dynamics: coupling fire into a dynamic global vegetation model. Global Ecol. 673 Biogeog. 10, 661-677.

674 Toniato, M.T.Z., Leitão-Filho, H.F., Rodrigues, R.R., 1998. Fitossociologia de um remanescente 675 de floresta higrófila (mata de brejo) em Campinas, SP. Rev. Bras. Bot. 21, 197-210.

676 Uhl, C., Clark, K., Dezzeo, N., Maquirino, P., 1988. Vegetation dynamics in Amazonian treefall 677 gaps. Ecology 69, 751-763.

678 Wittmann, F., Anhuf, D., Junk, W.J., 2002. Tree species distribution and community structure of 679 Central Amazonian várzea forests by remote-sensing techniques. J. Trop. Ecol. 18, 805-820. 680 Wittmann, F., Junk, W.J., Piedade, M.T.F., 2004. The várzea forests in Amazonia: flooding and 681 the highly dynamic geomorphology interact with natural forest succession. Forest Ecol. 682 Manag. 196, 199-212.

683 


\section{List of tables}

Table 1. Number of individuals $\left(\mathrm{ha}^{-1}\right)$ and basal area $\left(\mathrm{m}^{2} \mathrm{ha}^{-1}\right)$ of the woody vegetation sampled in two impucas (seasonally flooded forests) for burned and unburned plots, and your respective percentage of change between years (2007 and 2010). The fire occurred in 2007 following the 2007 census.

\begin{tabular}{|c|c|c|c|c|c|c|c|c|c|c|c|c|}
\hline & \multicolumn{6}{|c|}{ Impuca 1} & \multicolumn{6}{|c|}{ Impuca 2} \\
\hline & \multicolumn{3}{|c|}{ unburned } & \multicolumn{3}{|c|}{ burned } & \multicolumn{3}{|c|}{ unburned } & \multicolumn{3}{|c|}{ burned } \\
\hline & 2007 & 2010 & $\%$ change & 2007 & 2010 & $\%$ change & 2007 & 2010 & $\%$ change & 2007 & 2010 & $\%$ change \\
\hline Number of individuals & 650 & 616 & 5.2 & 688 & 546 & 20.6 & 620 & 548 & 11.6 & 1,382 & 611 & 55.8 \\
\hline Basal area & 10.08 & 9.8 & 2.8 & 15.1 & 13.5 & 10.6 & 12.63 & 11.6 & 8.2 & 22.7 & 13.8 & 39.2 \\
\hline
\end{tabular}


Table 2. Parameters of the woody vegetation dynamics of burned and unburned sites of two seasonally flooded forests (impucas). $W=$ test of Mann-Whitney. $*=P<0.05, * *=P<0.01, * * *=P<0.001$, n.s. $=$ not significant.

\begin{tabular}{|c|c|c|c|c|c|c|}
\hline \multirow[b]{2}{*}{ PARAMETERS } & \multicolumn{2}{|c|}{ IMPUCA 1} & \multicolumn{4}{|c|}{ IMPUCA 2} \\
\hline & Unburned & Burned & $W$ & Unburned & Burned & $W$ \\
\hline Average annual mortality rates (individual-basis, $\%$ year $^{-1}$ ) & 3.7 & 8.0 & $149.00 * *$ & 5.2 & 24.3 & $22.00 * * *$ \\
\hline Average annual recruitment rates (individual -basis, $\%$ year $^{-1}$ ) & 2.0 & 0.7 & $431.50 * *$ & 1.2 & 0.7 & $349.50 *$ \\
\hline Average annual rates of gain (basal area-basis, $\%$ year $^{-1}$ ) & 0.6 & 0.2 & $398.00^{*}$ & 1.9 & 2.3 & n.s. \\
\hline Average annual rates of loss (basal area-basis, $\%$ year $^{-1}$ ) & 3.9 & 4.9 & $181.00 * *$ & 4.3 & 16.0 & $46.00 * * *$ \\
\hline Average annual mortality rates (basal area-basis, $\%$ year $^{-1}$ ) & 1.4 & 3.6 & $170.00 * *$ & 2.9 & 15.4 & $51.00 * * *$ \\
\hline Average annual recruitment rates (basal area-basis, $\%$ year $^{-1}$ ) & 0.4 & & & 0.2 & 0.1 & \\
\hline Half-life time (individual-basis, years) & 18.3 & 6.8 & $333.00 * *$ & 13.0 & 2.5 & $468.00 * * *$ \\
\hline Duplication time (individual-basis, years) & 38.6 & 131.1 & $469.50 * * *$ & 68.9 & 240.5 & $361.50 * *$ \\
\hline Turnover rate (individual-basis, years) & 28.4 & 69.0 & $424.50 * *$ & 40.9 & 121.5 & $366.00 * *$ \\
\hline Turnover rate (basal area-basis, years) & 91.2 & 428.2 & $390.00^{*}$ & 203.8 & 644.9 & $359.00 * *$ \\
\hline Half-life time (basal area-basis, years) & 17.3 & 14.2 & & 17.1 & 4.1 & \\
\hline Duplication time (basal area-basis, years) & 165.0 & 842.1 & & 390.6 & $1,285.6$ & \\
\hline Stability (individual-basis, years) & & 124.3 & & 55.9 & 238.0 & \\
\hline Stability (basal area-basis, years) & 147.6 & 827.9 & & 373.6 & $1,281.5$ & \\
\hline Recruits basal area $\left(\mathrm{m}^{2} \mathrm{ha}^{-1}\right)$ & 0.13 & 0.04 & & 0.07 & 0.04 & \\
\hline Dead basal area & 1.14 & 2.05 & & 1.45 & 9.02 & \\
\hline
\end{tabular}


Table 3. Parameters for vegetation dynamics of the 10 highest IV species (importance value) in 2007 for the burned and unburned sites of two seasonally flooded forests (impucas). The species are ordered according to the IV in $2007 . \mathrm{M}=$ mortality $\left(\%\right.$ year $\left.{ }^{-1}\right), \mathrm{R}=$ recruitment $\left(\%\right.$ year $\left.{ }^{-1}\right)$, $\mathrm{t}_{1 / 2}=$ half-life time (years), $\mathrm{t}_{2}=$ duplication time (years), $\mathrm{RBA}=$ recruits basal area $\left(\mathrm{m}^{2} \mathrm{ha}^{-1}\right), \mathrm{IBA}=$ basal area increment $\left(\mathrm{m}^{2}\right.$ ha $\left.{ }^{-1}\right), \mathrm{DBA}=\mathrm{decrement}$ in basal area $\left(\mathrm{m}^{2} \mathrm{ha}^{-1}\right), \mathrm{GBA}=$ gain in basal area $\left(\%\right.$ year $\left.{ }^{-1}\right), \mathrm{LBA}=$ loss in basal area $\left(\%\right.$ year $\left.{ }^{-1}\right)$.

\begin{tabular}{|c|c|c|c|c|c|c|c|}
\hline SPECIES & $\mathrm{M}$ & $\mathrm{R}$ & \multicolumn{2}{|c|}{ RBA IBA } & DBA & GBA & LBA \\
\hline \multicolumn{8}{|l|}{ IMPUCA 1 - unburned } \\
\hline Ochthocosmus multiflorus Ducke (Ixonanthaceae) & 3.4 & 2.0 & 0.02 & 0.07 & 0.03 & 1.4 & 2.1 \\
\hline Xylopia calophylla R.E.Fr. (Annonaceae) & 4.8 & 0.4 & 0.01 & 0.13 & 0 & 4.0 & 5.2 \\
\hline Tachigali bracteosa (Harms) Zarucchi \& Pipoly (Fabaceae) & 13.2 & 2.8 & 0.01 & 0.20 & 0.01 & 6.1 & 15.5 \\
\hline Licania apetala (E. Mey.) Fritsch (Chrysobalanaceae) & 1.1 & & 0.01 & 0.03 & 0.02 & 1.2 & 1.0 \\
\hline Leptolobium nitens Vogel (Fabaceae) & 3.1 & 0 & 0 & 0.03 & 0.01 & 1.0 & 2.5 \\
\hline Mabea paniculata Spruce ex Benth.(Euphorbiaceae) & & 3.5 & 0.01 & 0.02 & 0.01 & 4.6 & 3.8 \\
\hline Ormosia excelsa Benth. (Fabaceae) & & 0 & 0 & 0.05 & 0 & 3.0 & 0 \\
\hline Calophyllum brasiliense Cambess. (Calophyllaceae) & & 1.8 & 0.01 & 0.05 & 0 & 4.9 & 1.0 \\
\hline Diospyros tetrandra Hiern (Ebenaceae) & 1.7 & 0 & 0 & 0.04 & 0.01 & 2.5 & 0.3 \\
\hline Diospyros poeppigiana A. DC. (Ebenaceae) & 0 & 4.0 & 0.02 & 0.04 & 0 & 7.0 & 0 \\
\hline \multicolumn{8}{|l|}{ IMPUCA 1 - burned } \\
\hline Licania apetala (E. Mey.) Fritsch (Chrysobalanaceae) & 2.2 & 0.3 & 0.01 & 0.08 & 0.01 & 0.5 & 1.1 \\
\hline Tachigali bracteosa (Harms) Zarucchi \& Pipoly (Fabaceae) & 22.1 & 0 & 0 & 0.25 & 0.01 & 4.5 & 9.1 \\
\hline Duroia prancei Steyerm. (Rubiaceae) & 8.12 & 0.7 & 0.01 & 0.03 & 0.03 & 1.9 & 6.4 \\
\hline Leptolobium nitens Vogel (Fabaceae) & 3.3 & 0 & 0 & 0.08 & 0.01 & 2.7 & 2.8 \\
\hline Mabea paniculata Spruce ex Benth. (Euphorbiaceae) & 7.2 & 0.8 & 0.01 & 0.02 & 0.05 & 1.9 & 8.7 \\
\hline Ormosia excelsa Benth. (Fabaceae) & 5.2 & 1.1 & 0.01 & 0.08 & 0.02 & 2.5 & 4.1 \\
\hline Ochthocosmus multiflorus Ducke (Ixonanthaceae) & 9.5 & 3.1 & 0.01 & 0.02 & 0.01 & 5.2 & 14.6 \\
\hline Calophyllum brasiliense Cambess. (Calophyllaceae) & 19.1 & 0 & 0 & 0.08 & 0.01 & 4.3 & 8.9 \\
\hline Mauritiella armata (Mart.) Burret (Arecaceae) & 15.3 & 3.6 & 0.01 & 0.01 & 0.03 & 2.8 & 18.5 \\
\hline Pera schomburgkiana (Klotzsch) Müll. Arg. (Peraceae) & 3.1 & 0 & 0 & 0.01 & 0.03 & 0.5 & 3.1 \\
\hline
\end{tabular}




\begin{tabular}{|c|c|c|c|c|c|c|c|}
\hline \multicolumn{8}{|l|}{ IMPUCA 2 - unburned } \\
\hline Micropholis gardneriana (A. DC.) Pierre (Sapotaceae) & 5.1 & 0.9 & 0.01 & 0.13 & 0.01 & 1.6 & 5.4 \\
\hline Licania kunthiana Hook. f. (Fabaceae) & 4.3 & 0 & 0 & 0.05 & 0.01 & 1.3 & 4.5 \\
\hline Licania apetala (E. Mey.) Fritsch (Fabaceae) & 1.8 & 0 & 0 & 0.02 & 0.01 & 0.5 & 0.6 \\
\hline Diospyros tetrandra Hiern (Ebenaceae) & 4.6 & 0 & & 0.07 & 0.04 & 1.8 & 3.3 \\
\hline Ternstroemia candolleana Wawra (Pentaphylacaceae) & 1.5 & 0 & & 0.02 & 0.01 & 1.5 & 0.5 \\
\hline Symmeria paniculata Benth. (Poligonaceae) & 7.9 & 5.0 & .02 & 0.03 & 0.01 & 7.0 & 4.7 \\
\hline Ochthocosmus multiflorus Ducke (Ixonanthaceae) & 2.2 & & 0.01 & 0.01 & 0.01 & 1.1 & 1.9 \\
\hline Roupala montana Aubl. (Proteaceae) & 3.3 & & 0 & 0.02 & 0.01 & 1.6 & 1.4 \\
\hline Eschweilera ovata (Cambess.) Miers (Lecythidaceae) & & & 0 & 0.02 & 0 & 2.0 & 5.3 \\
\hline Combretum laxum Jacq. (Combretaceae) & 9.1 & 0 & 0 & 0.01 & 0.01 & 2.4 & 4.3 \\
\hline \multicolumn{8}{|l|}{ IMPUCA 2 - burned } \\
\hline Micropholis gardneriana (A. DC.) Pierre (Sapotaceae) & & 0.7 & 0.01 & 0.16 & 0.01 & 1.9 & 13.6 \\
\hline Calophyllum brasiliense Cambess. (Calophyllaceae) & & 0 & 0 & 0.17 & 0 & 3.0 & 18.7 \\
\hline Licania kunthiana Hook. f. (Fabaceae) & 13.9 & 0 & 0 & 0.09 & 0.01 & 2.2 & 8.3 \\
\hline Ochthocosmus multiflorus Ducke (Ixonanthaceae) & 20.8 & 1.0 & 0.01 & 0.03 & 0.01 & 2.1 & 13.8 \\
\hline Combretum laxum Jacq. (Combretaceae) & 67.2 & 7.2 & 0.01 & 0.01 & 0.01 & 4.9 & 47.1 \\
\hline Diospyros poeppigiana A. DC. (Ebenaceae) & 27.5 & 0 & 0 & 0.02 & 0.01 & 1.5 & 21.5 \\
\hline Roupala montana Aubl. (Proteaceae) & 24.4 & 0 & 0 & 0.03 & 0.01 & 1.9 & 17.7 \\
\hline Ternstroemia candolleana Wawra (Pentaphylacaceae) & 25.3 & 0 & 0 & 0.02 & 0.01 & 1.5 & 24.2 \\
\hline Sloanea garckeana K. Schum. (Elaeocarpaceae) & 13.9 & 0 & 0 & 0.04 & 0.03 & 1.4 & 6.4 \\
\hline Eschweilera ovata (Cambess.) Miers (Lecythidaceae) & 18.1 & 0 & 0 & 0.06 & 0.01 & 3.9 & 10.1 \\
\hline
\end{tabular}




\section{List of figures}

Fig. 1. Location of the seasonally flooded forests (impucas) sampled in the Araguaia State Park (PEA), State of Mato Grosso, and arrangement of the plots in the transects established in each impuca. 四 = burned subplots and $=\square$ unburned subplots.

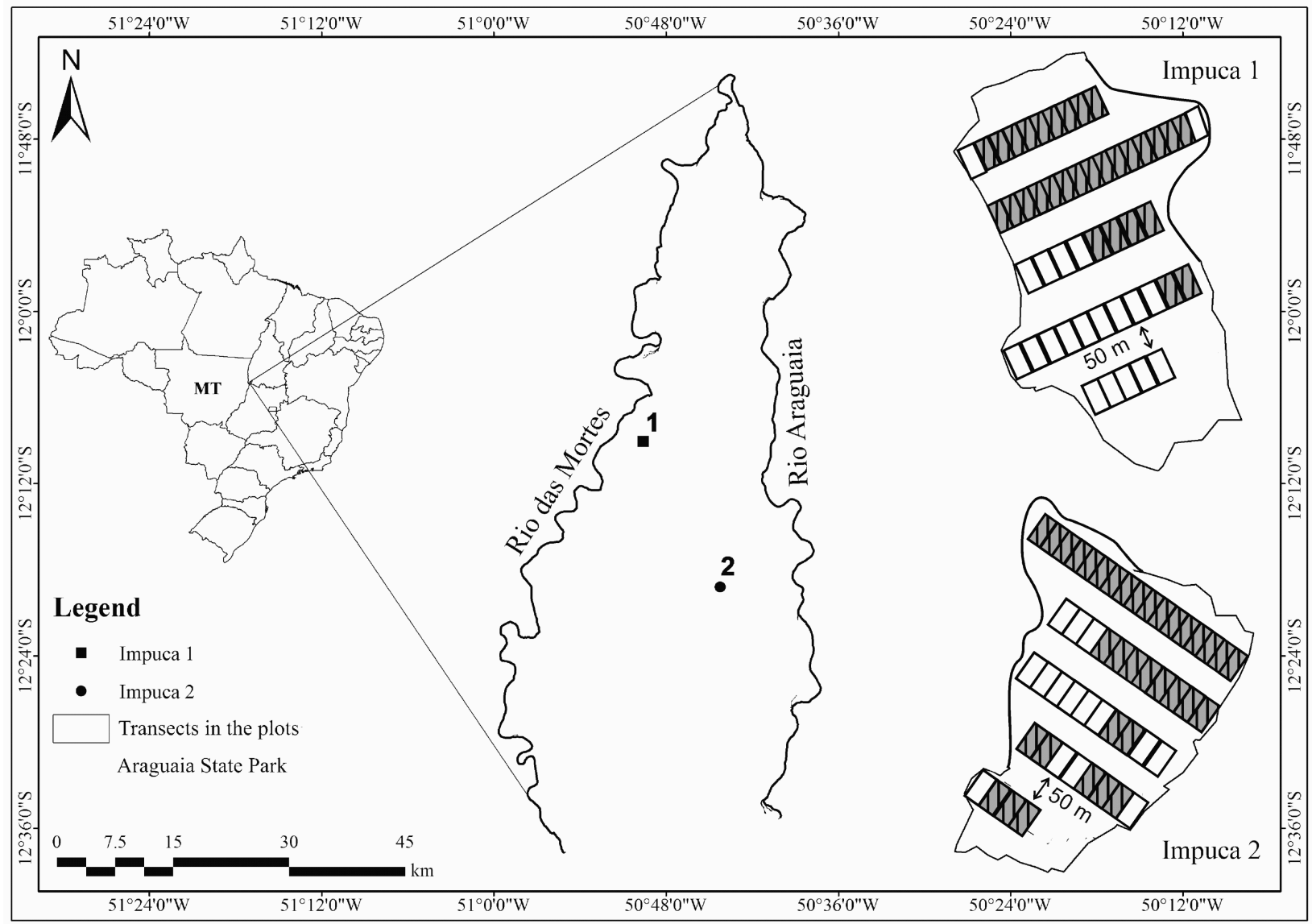


Fig. 2. Structural changes and dynamics of the woody vegetation between the years 2007 and 2010 by diameter classes of the burned and unburned sites of a seasonally flooded forest (impucas 1 and 2). $\mathrm{A}$ and $\mathrm{C}=$ Average annual rate of loss in basal area and average annual rate of mortality; $\mathrm{B}$ and $\mathrm{D}=$ Average annual rate of gain in basal area and average annual rate of recruitment; $\mathrm{UN}=$ unburned site and $\mathrm{BU}=$ burned site.
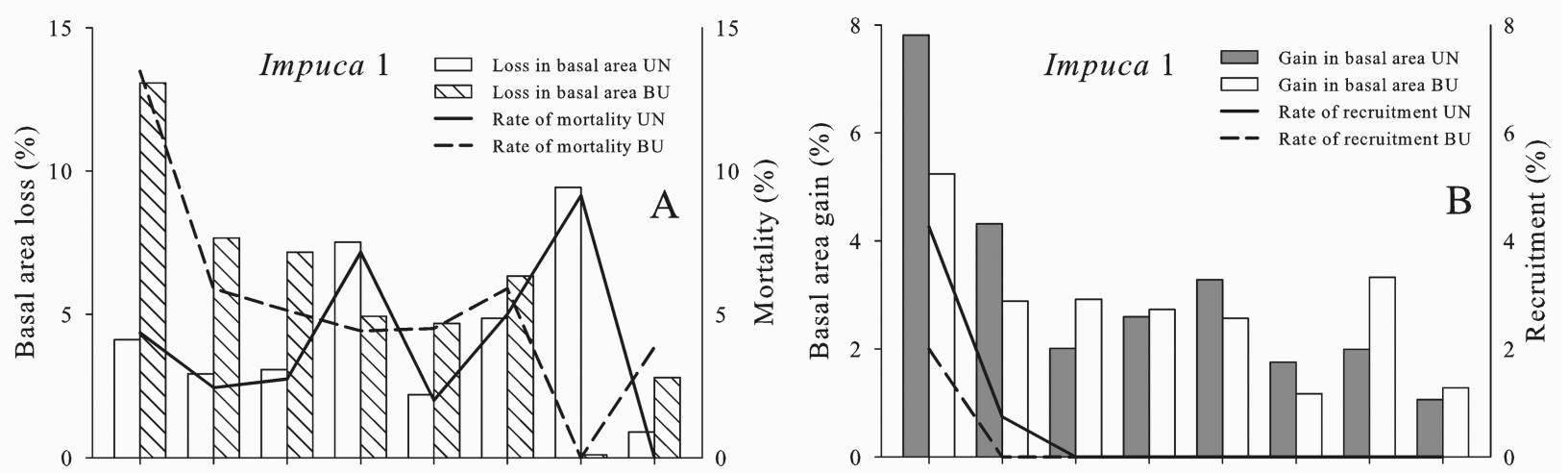

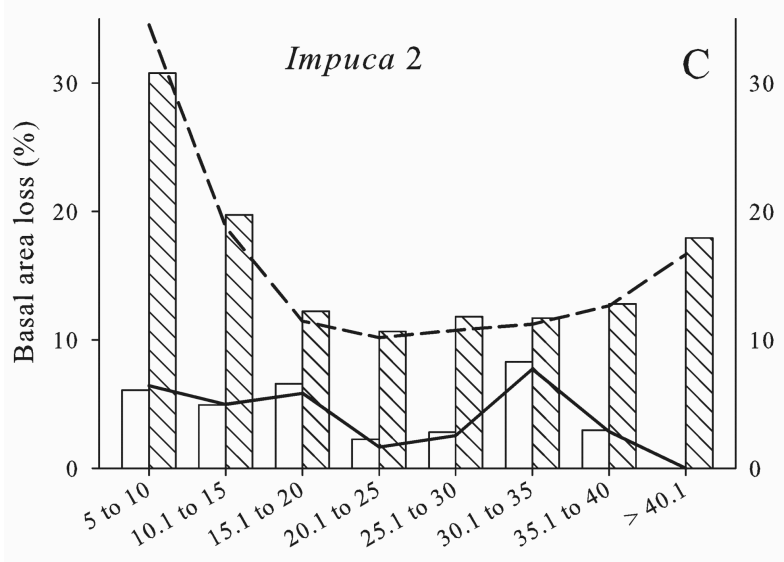

Diameter classes $(\mathrm{cm})$

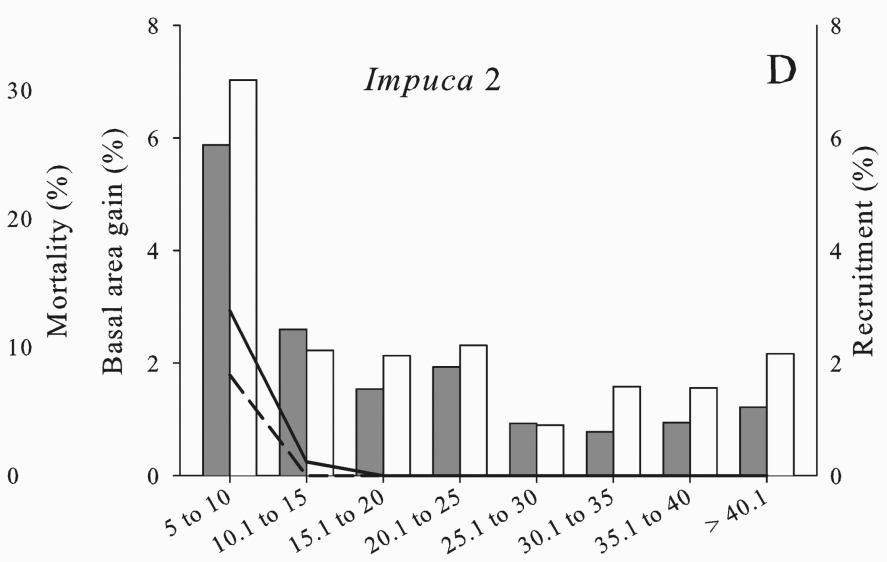

Diameter classes $(\mathrm{cm})$ 
Fig. 3. Structural changes and dynamics of the woody vegetation by diameter classes of the burned and unburned sites of a seasonally flooded forest (impucas 1 and 2). Number of the ingrowth (given by the entry of trees into a class by recruitment and growth) and outgrowth (given by the output of trees of a class by growth) considering both individual- and basal areabasis; $\mathrm{UN}=$ unburned site and $\mathrm{BU}=$ burned site.
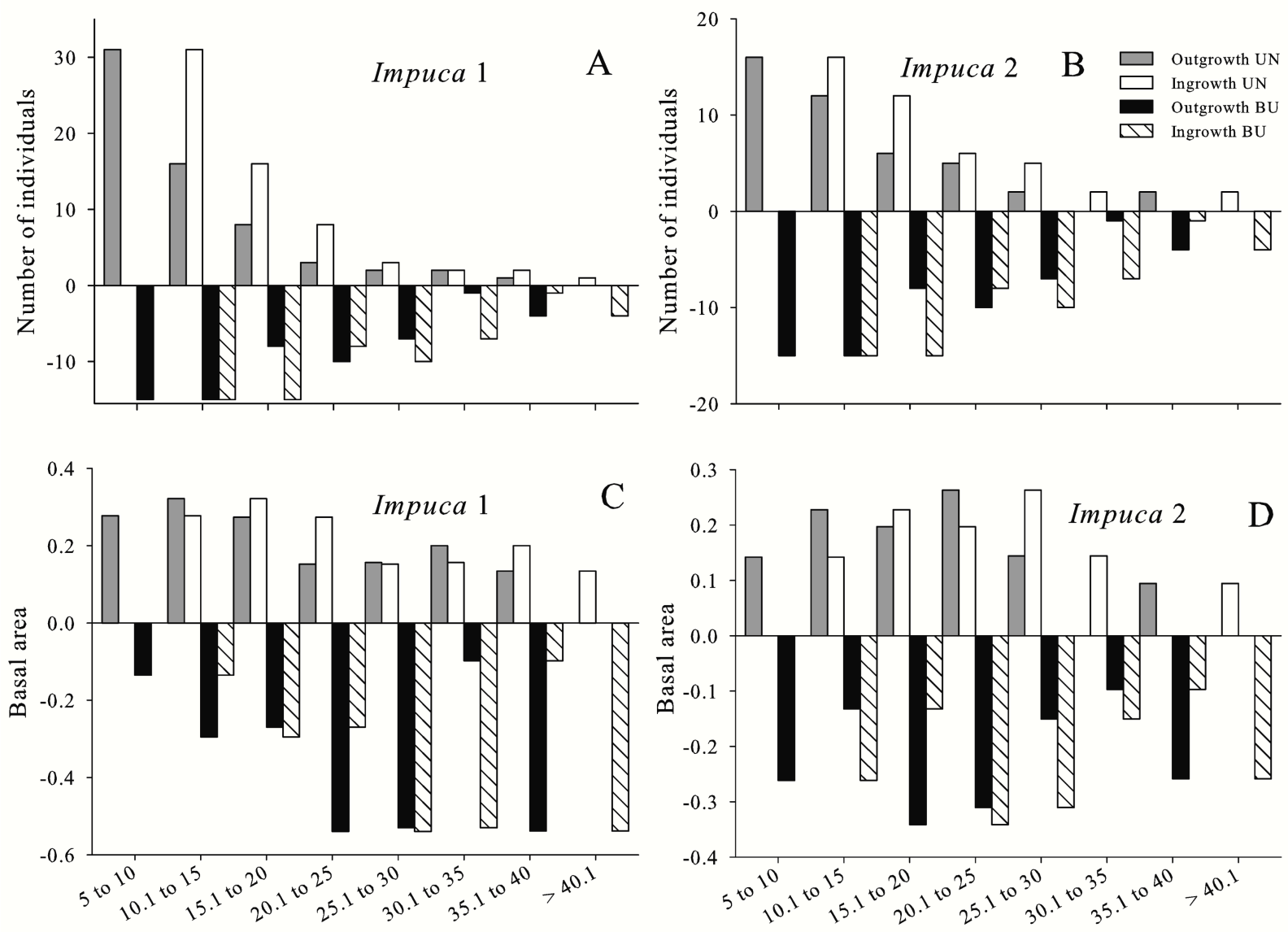

Diameter classes $(\mathrm{cm})$

Diameter classes $(\mathrm{cm})$ 
Fig. 4. Changing parameters of the woody vegetation by diameter classes of the burned and unburned sites of seasonally flooded forests (impuca 1 and 2). $\mathrm{A}$ and $\mathrm{B}=$ Changing parameters in number of individuals and $\mathrm{C}$ and $\mathrm{D}=$ Changing parameters in basal area; $\mathrm{UN}=$ unburned site and $\mathrm{BU}=$ burned site.
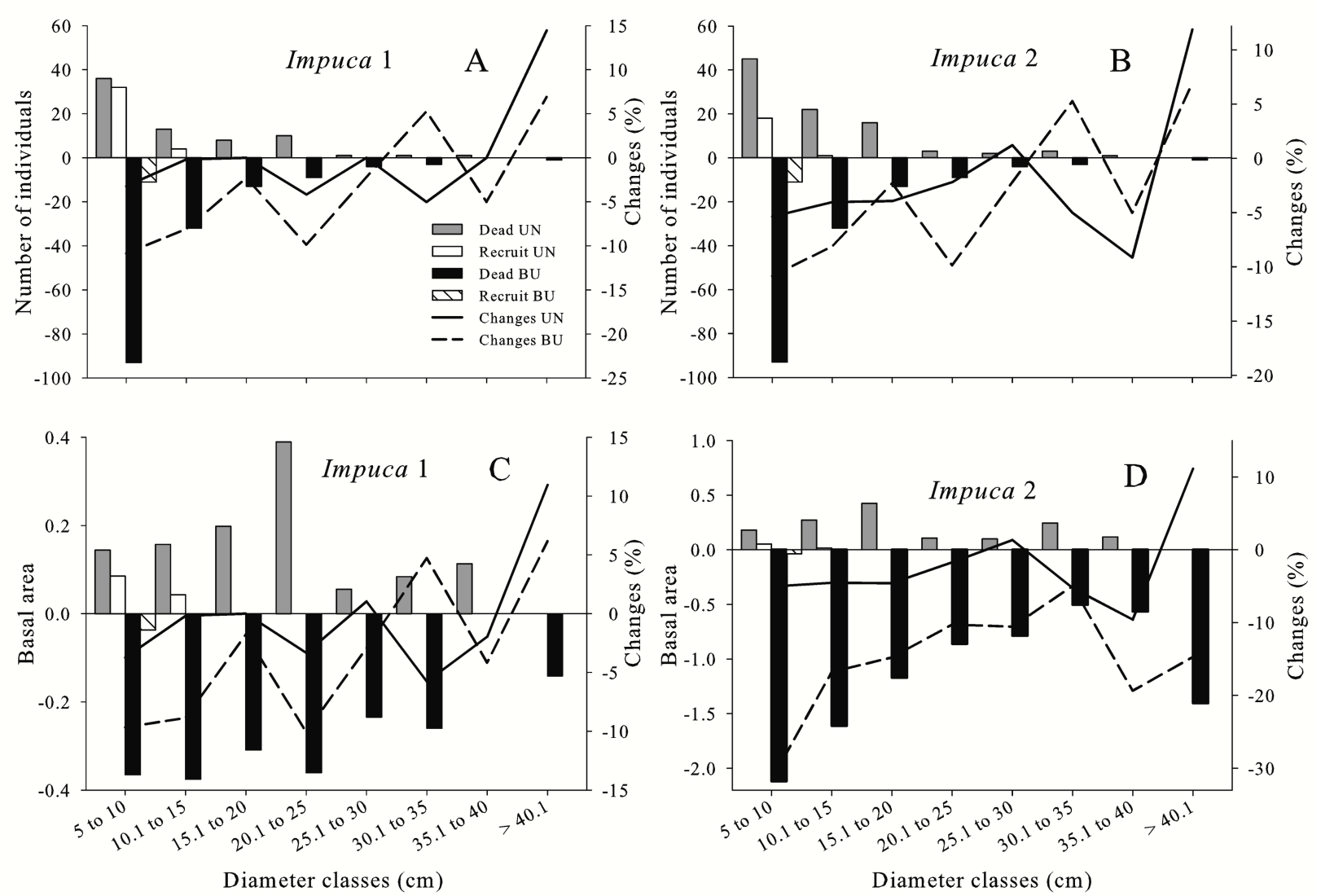